\title{
PENGARUH STRUKTUR MODAL, PERPUTARAN PERSEDIAAN DAN PERPUTARAN KAS TERHADAP PROFITABILITAS DI BEI
}

\author{
Siti Halima Nur Aini \\ Darman \\ Program Studi S1 Manajemen Fakultas Ekonomi dan Bisnis Universitas Tadulako \\ Email: sitihalimahnuraini97@gmail.com;darman tadulako@yahoo.com
}

\begin{abstract}
The purpose of this study was to determine the effect of capital structure, inventory turnover and cash turnover on profitability both simultaneously and partially in the automotive sub sector companies and other components listed on the Indonesia stock exchange in 2013-2017 totaling 12 companies, with sampling techniques conducted by purposive sampling, wich then from the chosen criteria selected 6 companies on one year, so that the total sample during the study period amounted to 30 companies. The hypothesis inthis study uses multiple linear regression. The dependent variable is profitability which is measured using the return on equity (ROE) ratio, while the independent variable is the capital strukture which is measured using the debt to equity ratio (DER) ratio, inventory turnover and cash tutnover. The results of this study indicate that the variable capital structure and cash turnover partially do not affect profitability, and inventory turnover variables partially affect profitability. Simultaneously capital structure variables, inventory turnover and cash turnover affect profitability.
\end{abstract}

Keywords : Capital Structure, Inventory Turnover, Cash Turnover, Profitability

Abstrak

Tujuan dari penelitian ini adalah untuk mengetahui pengaruh struktur modal, perputaran persediaan dan perputaran kas terhadap profitabilitas baik secara simultan maupun parsial pada perusahaan sub sektor otomotif dan komponen yang terdaftar di Bursa Efek Indonesia. Populasi dalam penelitian ini adalah perusahaan sub sektor otomotif dan komponen lainnya yang terdaftar di Bursa Efek Indonesia tahun 2013-2017 berjumlah 12 perusahaan, dengan teknik pengambilan sampel dilakukan dengan purposive sampling yang selanjutnya dari kriteria yang ditetapkan terpilih 6 perusahaan dalam satu tahun, sehingga total sampel selama periode penelitian berjumlah 30 perusahaan. Hipotesis dalam penelitian ini menggunakan regresi linier berganda. Variabel dependen yaitu profitabilitas yang diukur menggunakan rasio Return On Equity (ROE), sedangkan variabel independen yaitu struktur modal yang diukur menggunakan rasio Debt To Equity Ratio (DER), perputaran persediaan dan perputaran kas. Hasil dari penelitian ini menunjukkan bahwa variabel struktur modal dan perputaran kas secara parsial tidak berpengaruh terhadap profitabilitas, dan variabel perputaran persediaan secara parsial berpengaruh terhadap profitabilitas. Secara simultan variabel struktur modal, perputaran persediaan, perputaran kas berpengaruh terhadap profitabilitas

\section{Kata kunci: Struktur Modal, Perputaran Persediaan, Perputaran Kas, Profitabilitas}

\section{PENDAHULUAN}

Tujuan suatu perusahaan yang terutama adalah mencapai keuntungan yang maksimal. Sehingga perusahaan perlu mengetahui perkembangan perusahaannya untuk meningkatkan labanya. Tingkat efektivitas manajemen yang ditunjukkan dari laba hasil penjualan atau pendapatan investasi dapat diketahui melalui rasio profitabilitas (Kasmir, 2010:114). Dalam penelitian rasio profitabilitas diukur menggunakan ROE. Alasan digunakannya ROE karena rasio ini bisa digunakan buat mengukur tingkat pengembalian 
yang dihasilkan dari investasi. Tingginya ROE menandakan semakin tinggi kinerja suatu perusahaan. Penggunaan hutang akan meningkatkan Return on Equity apabila target penjualan terpenuhi dan laba perusahaan meningkat, namun bisa juga sebaliknya.

Struktur modal mempunyai peran yang sangat penting untuk perusahaan karena menyangkut keputusan penggunaan sumber dana yang sangat menguntungkan. Menurut Ambarwati (2010:2) berpendapat bahwa masalah leverage masuk karena perusahaan menggunakan aset yang menyebabkan harus membayar biaya tetap. Oleh karena itu, peneliti menggunakan rasio hutang yaitu Debt To Equity Ratio pada penelitian ini untuk mengukur struktur modal. Tujuan manajemen modal kerja adalah mengatur aktiva lancar dan hutang lancar maka didapatkan modal kerja neto yang cocok dan menjamin kualitas likuiditas perusahaan (Harjito dan Martono, 2014:74). Menurut Riyanto (2004), kas merupakan salah satu bagian modal kerja yang sangat tinggi likuiditasnya sehingga semakin besar jumlah kas yang dimiliki maka semakin tinggi tingkat likuiditasnya. Ini berarti perusahaan memiliki dampak yang makin kecil untuk tidak dapat mencukupi tanggung jawab finansialnya. Tetapi ini tidak berarti bahwa perusahaan layak melindungi persediaan kas yang besar, karena semakin besar kas akan mengakibatkan banyaknya uang menganggur sehingga akan memperkecil keuntungan. Tetapi suatu perusahaan yang hanya mengejar keuntungan tanpa memerhatikan likuiditasnya, maka perusahaan tersebut akan dalam keadaan likuid jika sewaktu-waktu ada tagihan.

Komponen penting modal kerja selain kas adalah persediaan. Persediaan sangat dibutuhkan oleh perusahaan guna menjaga kelancaran proses produksi sehingga mampu memengaruhi profitabilitas perusahaan, terutama perusahaan manufaktur yang sebagian besar kegiatan jalan produksi memerlukan adanya persediaan.Apabila persediaan terlalu besar, maka biaya yang ditanggung perusahaan akan bertambah, dan meningkatkan risiko kerusakan karena penyimpanan yang lama, sehingga menurunkan kualitasnya.

Objek dalam penelitian ini adalah adalah perusahaan sub sektor otomotif dan komponen yang terdaftar di Bursa Efek Indonesia periode tahun 2013-2017.

\section{KAJIAN LITERATURE}

\section{Analisis Laporan Keuangan}

Analisis laporan keuangan merupakan alat analisis bagi manajemen keuangan perusahaan yang bersifat merata, dapat digunakan untuk mengetahui tingkat kesehatan perusahaan, melalui analisis keadaan arus kas atau kinerja organisasi perusahaan baik yang bersifat parsial maupun secara keseluruhan ( Harmono, 2017:104).

\section{Struktur Modal}

Menurut Ambarwati (2010:1) struktur modal adalah perbandingan antara utang dan modal sendiri (saham preferen dan saham biasa) yang digunakan perusahaan guna merancangkan bagaimana mendapatkan modal. Dalam membiayai kebutuhan pendanaan perusahaan dapat menggunakan modal sendiri dan modal asing atau utang. Jika memanfaatkan utang maka perusahaan akan membiayai dana tetap yaitu bunga. 


\section{Komponen Struktur Modal}

Struktur modal suatu perusahaan secara umum terdiri atas beberapa komponen, yaitu :

a. Modal sendiri

Menurut Riyanto (2001:240) modal sendiri adalah dana yang berasal dari pemilik dan tersimpan di dalam perusahaan untuk waktu yang tidak tertentu lamanya. Sedangkan menurut Sutojo dan Kleinsteuber (2002:20) modal sendiri adalah modal yang dipinjam dalam waktu tak tertentu dari para pemegang saham.

b. Utang Jangka Panjang

Menurut Riyanto (2001:238) utang jangka panjang juga dapat diartikan sebagai tanggung jawab keuangan yang jangka waktu pembayarannya (jatuh temponya) lebih dari satu tahun mulai tanggal neraca.

\section{Pengukuran Struktur Modal}

Dalam praktek analisa rasio ini dihitung dengan menggunakan Debt to Equity Ratio (DER). Rasio ini mendeskripsikan perbandingan utang dan modal sendiri dalam pendanaan perusahaan dan menandakan kemampuan modal sendiri perusahaan untuk mencukupi semua kewajibannya.

Menurut Megginon dalam Mulyawan (2015), teori-teori struktur modal yang dikenal oleh perusahaan dalam menetapkan struktur modal, yaitu :

1. Teori Miller dan Modligiani (M\&M)

Teori ini memberikan penjelasan operasional dari biaya modal dan dasar teori investasi yang secara akurat mengakui ketidakpastian dan memberikan dorongan sebagai dasar prinsip dan maksimalisasi nilai pasar.

2. Teori signaling

Signaling merupakan kegiatan pendanaan manajer yang dipercaya dapat merefleksikan nilai dari saham perusahaan. Pada umumnya pendanaan dengan utang dianggap sebagai signal positif sehingga manajer percaya bahwa saham undervalued.

3. Teori Trade Off

Teori ini membahas tentang hubungan antara struktur modal dengan nilai perusahaan. Model trade off beranggapan bahwa struktur modal perusahaan merupakan hasil trade off dari keuntungan pajak dengan menggunakan hutang dengan biaya yang akan muncul sebagai dampak penggunaan hutang tersebut.

\section{Modal Kerja}

Dana yang diperlukan oleh perusahaan untuk mencukupi kebutuhan operasional perusahaan sehari-hari, seperti pembelian bahan baku, pembayaran gaji buruh, membayar hutang, dan pembayaran lainnya disebut modal kerja (Sutrisno, 2013:41).

\section{Pengukuran Modal Kerja}

1) Perputaran Persediaan

Menurut Riyanto (2004), Inventory atau persediaan sebagai elemen yang utama dari modal kerja merupakan aktiva yang selalu dalam keadaan berputar, dimana secara terus menerus mengalami perubahan.

Adanya investasi dalam inventory yang terlalu besar dibandingkan dengan kebutuhan akan memperbesar beban bunga, memperbesar biaya penyimpanan dan pemeliharaan gudang, kemungkinan kerugian karena kerusakan, turunnya bobot, sehingga semuanya akan memperkecil keuntungan perusahaan. 
2) Perputaran Kas

Menurut Riyanto (2004), kas merupakan salah satu unsur modal kerja yang paling tinggi likuiditasnya yang berarti bahwa semakin besar jumlah kas yang dimiliki suatu perusahaan akan semakin tinggi pula tingkat likuiditasnya. Ini berarti bahwa perusahaan mempunyai efek yang lebih kecil untuk tidak dapat memenuhi kewajiban finansialnya. Tetapi ini tidak berarti bahwa perusahaan harus melindungi persediaan kas yang sangat besar, karena semakin besar kas akan menyebabkan banyaknya uang menganggur sehingga akan memperkecil keuntungan.

\section{METODE PENELITIAN}

Jenis penelitian ini adalah penelitian kuantitatif yang dapat diartikan sebagai metode penelitian yang berlandaskan pada filsafat positivisme, digunakan untuk meneliti pada populasi atau sampel tertentu, pengumpulan data menggunakan instrumen penelitian, analisis data bersifat kuantitatif atau statistik, dengan tujuan untuk menguji hipotesis yang ditetapkan (Sugiyono, 2015:35). Jenis data yang digunakan dalam penelitian ini adalah data kuantitatif. Data kuantitatif adalah data yang dipaparkan dalam bentuk angka-angka dengan cara mengumpulkan data-data yang menjadi pendukung terhadap pengaruh antara variabel-variabel yang bersangkutan untuk dianalisis. Data yang digunakan dalam penelitian ini adalah data sekunder yaitu data yang diperoleh secara tidak langsung melalui media perantara yang diperoleh dan dicatat oleh pihak lain. Data tersebut telah dipublikasikan oleh PT. Bursa Efek Indonesia (www.idx.co.id). Selain itu data-data lainnya diperoleh dari berbagai studi pustaka pada literatur-literatur, jurnal-jurnal, dan hasil penelitian yang diperoleh dari berbagai sumber yang dapat mendukung dan memberikan informasi yang objektif. Metode pengumpulan data dalam penelitian ini menggunakan metode dokumentasi dari website Bursa Efek Indonesia (www.idx.co.id) pada tahun 2013-2017 dengan mengambil data laporan keuangan dari perusahaan sub sektor otomotif dan komponen yang terdaftar dalam Bursa Efek Indonesia tahun 2013-2017.

Populasi dalam penelitian ini adalah perusahaan sub sektor otomotif dan komponen yang terdaftar di Bursa Efek Indonesia yang berjumlah 12 perusahaan pada periode 2013-2017. Sampel yang digunakan dalam penelitian ini, diambil menggunakan teknik purposive sampling, yaitu teknik penentuan sampel dengan pertimbangan tertentu (Sugiyono, 2015:156) yang akhirnya diperoleh sampel sebanyak 6 perusahaan.

Variabel Penelitian dalam penelitian ini adalah :

a) Variabel Dependen (Variabel Y)

Variabel dependen atau yang sering disebut dengan variabel terikat, merupakan variabel yang dipengaruhi atau yang menjadi akibat karena adanya variabel bebas (variabel independen). Di dalam penelitian ini, variabel dependen yang akan digunakan adalah profitabilitas yang diukur menggunakan rasio ROE.

b) Variabel Independen (Variabel X)

Variabel independen atau yang sering disebut dengan variabel bebas, merupakan variabel yang memengaruhi atau menjadi penyebab perubahan dan timbulnya variabel dependen (terikat). Variabel independen yang akan digunakan, meliputi : struktur modal yang diukur menggunakan rasio DER, perputaran persediaan dan perputaran kas.

Operasionalisasi variabel independen dan variabel dependen dalam penelitian ini akan disajikan dalam Tabel 3.3 
Tabel 1. Operasionalisasi Variabel

\begin{tabular}{llcc}
\hline Variabel & Indikasi & Formulasi & Skala \\
\hline Struktur modal & Total hutang & DER $=\frac{\text { Total Utang }}{\text { Modal sendiri }} \times 100 \%$ & Rasio \\
(DER) X1 & Modal sendiri & Kasmir, 2010:112 & \\
\hline Perputaran & -HPP, & perputaran persedia $=\frac{\text { harga pokok penjualan }}{\text { rata rata persediaan }}$ & Rasio \\
Persediaan X2 & rata-rata Persediaan & Riyanto, 2004 & \\
Perputaran Kas & -Penjualan bersih, & Perputaran kas $=\frac{\text { penjualan bersih }}{\text { rata-rata kas }}$ & Rasio \\
X3 & rata-rata kas & Riyanto, 2004 & \\
\hline Profitabilitas & -EAT & ROE $=\frac{\text { EAT }}{\text { Modal sendiri }} \times 100 \%$ & Rasio \\
(ROE) Y & -Modal sendiri & Sutrisno, 2013 & \\
\hline
\end{tabular}

Sumber: berbagai buku dan rujukan lainnya

Teknik analisis data yang digunakan dalam penelitian ini adalah teknik analisis regresi linear berganda. Analisis regresi linear berganda merupakan suatu metode analisis statistik yang mempelajari hubungan antara dua atau lebih variabel. Model analisis regresi linear berganda digunakan untuk mengetahui pengaruh variabel-variabel bebas terhadap variabel-variabel terikat. Regresi linear berganda mempunyai ciri sebagai berikut, persamaan fungsinya dapat diformulasikan ke dalam bentuk persamaan matematika, sebaran datanya berdistribusi normal, bilangan datanya rasional, nilai parameternya ditentukan oleh $\alpha$ dan $\beta$ yang dapat diukur menggunakan uji statistik melalui program $\mathrm{p}$ dalam komputer, permasalahannya lebih dari satu variabel, variabel terikatnya cukup jelas. Model ini dipilih karena ingin mengetahui besarnya kontribusi pengaruh variabel bebas terhadap variabel terikat baik secara parsial maupun secara simultan yang didukung oleh uji normalitas, uji multikolinearitas, uji heterokedastisitas, dan uji autokorelasi. Setelah data diolah dan dianalisis secara kuantitatif dilakukan analisis secara kualitatif untuk memberikan penjelasan atau makna dari hasil analisis kuantitatif.

Adapun formulasi regresi linear berganda mengacu dengan formulasi yang diajukan oleh Sugiyono (2015) :

$$
\mathrm{Y}=\mathrm{a}+\mathrm{b} 1 \mathrm{X} 1+\mathrm{b} 2 \mathrm{X} 2+\mathrm{b} 3 \mathrm{X} 3+\mathrm{b} 4 \mathrm{X} 4+\mathrm{e}
$$

$$
\begin{aligned}
& \mathrm{Y} \quad=\text { profitabilitas }(\mathrm{ROE}) \\
& \text { a } \quad=\text { konstanta } \\
& \text { b1-3 = Koefisien regresi } \\
& \mathrm{X} 1=\text { struktur modal (DER) } \\
& \mathrm{X} 2=\text { Perputaran persediaan } \\
& \mathrm{X} 3=\text { Perputaran Kas } \\
& \text { e }=\text { eror }
\end{aligned}
$$

\section{Statistik Deskriptif}

Statistik deskriptif adalah statistik yang digunakan untuk menganalisis data dengan cara mennguraikan atau menggunakan data yang telah terkumpul sebagaimana adanya tanpa bermaksud membuat kesimpulan yang berlaku untuk umum (sugiyono, 2015:238). 


\section{Uji Asumsi Klasik}

Uji Normalitas

Uji normalitas bertujuan untuk menguji apakah dalam sebuah model regresi, variabel dependen, variabel independen atau keduanya mempunyai distribusi normal atau tidak. Model regresi yang baik adalah distribusi data normal atau mendekati normal.

Dasar pengambilan keputusan untuk uji normalitas adalah :

1. Jika data menyebar disekitar garis diagonal dan mengikuti arah garis diagonal, maka model regresi memenuhi asumsi normalitas.

2. Jika data menyebar jauh dari garis diagonal atau tidak mengikuti arah garis diagonal maka model regresi tidak memenuhi asumsi normalitas.

Uji Multikolinearitas

Uji Multikolinearitas dilakukan untuk melihat apakah ada sangkutan antara hubungan yang sempurna antara variabel-variabel independen.

Uji Heterokedastisitas

Uji heterokedastisitas bertujuan untuk menguji apakah dalam model regresi terjadi tidaksamaan varian dari residual satu pengamatan kepengamatan yang lain. Jika varian dari satu pengamatan kepengamatan lain tetap, maka disebut homokedastisitas dan apabila berbeda maka terjadi heterokedastisitas.

Uji Autokorelasi

Metode pengujian yang sering digunakan adalah dengan uji Durbin-Watson (uji DW), namun pada penelitian ini saya menggunakan uji run test dengan ketentuan sebagai berikut:

1. Jika nilai Asymp. Sig. (2-tailed) lebih kecil $<$ dari 0,05 maka terdapat gejala autokorelasi.

2. Sebaliknya, jika nilai Asymp. Sig. (2-tailed) lebih besar $>$ dari 0,05 maka tidak terdapat gejala autokorelasi.

\section{HASIL DAN PEMBAHASAN}

Tabel 2. Perkembangan Return On Equity Perusahaan Otomotif Dan Komponen Lainnya Yang Terdaftar Di BEI Periode 2013-2017

\begin{tabular}{|c|c|c|c|c|c|c|}
\hline \multirow{2}{*}{ KODE } & \multicolumn{5}{|c|}{ Tahun } & \multirow{2}{*}{$\begin{array}{c}\text { Rata-rata } \\
\text { per } \\
\text { perusahaan }\end{array}$} \\
\hline & 2013 & 2014 & 2015 & 2016 & 2017 & \\
\hline ASII & 21,00 & 18,39 & 12,34 & 13,08 & 14,82 & 15,93 \\
\hline AUTO & 11,07 & 9,44 & 3,18 & 4,59 & 5,09 & 6,67 \\
\hline BRAM & 3,40 & 8,89 & 6,87 & 11,28 & 11,32 & 8,35 \\
\hline INDS & 8,42 & 6,98 & 0,10 & 2,40 & 5,30 & 4,64 \\
\hline NIPS & 14,36 & 8,71 & 5,04 & 7,80 & 5,02 & 8,19 \\
\hline SMSM & 33,59 & 36,75 & 32,03 & 31,78 & 30,38 & 32,91 \\
\hline $\begin{array}{l}\text { Rata-rata per } \\
\text { tahun }\end{array}$ & 15,31 & 14,86 & 9,93 & 11,82 & 12,00 & \\
\hline
\end{tabular}

Sumber: data diolah peneliti, 2019

Berdasarkan tabel 2 memberikan informasi bahwa rata-rata tingkat profitabilitas dari 6 perusahaan cenderung menurun dari tahun 2013 sampai 2015, dimana pada tahun 2013 tingkat profitabilitas adalah sebesar 15,31\% menjadi 9,93\% tahun 2015, dan pada tahun 2016 sampai tahun 2017 tingkat profitabilitas mengalami peningkatan namun tidak terlalu signifikan, yaitu dari 
$11,82 \%$ menjadi $12,00 \%$. Dengan demikian dapat diartikan bahwa kemampuan manajemen perusahaan dalam mengelola ekuitasnya untuk memperoleh laba masih kurang efisien. Selama tahun periode penelitian, perusahaan SMSM memiliki tingkat profitabilitas paling tinggi pada tahun 2014 yaitu sebesar 36,75\% meskipun tiga tahun berikutnya nilainya menurun. Meskipun begitu, perusahaan SMSM memiliki tingkat profitabilitas paling tinggi diantara enam perusahaan selama tahun penelitian. Maka dapat diartikan apabila ROE pada perusahaan rendah maka manajemen perusahaan tidak efisien dalam menggunakan ekuitasnya. Semakin tinggi ROE pada perusahaan dapat mencerminkan bahwa manajemen perusahaan mampu dan efisien dalam menggunakan ekuitasnya untuk memperoleh laba.

\section{Uji Hipotesis}

a. Uji T

Tabel 3. Hasil Uji Statistik T

\begin{tabular}{lrrrc}
\multicolumn{4}{c}{ Coefficients $^{\mathrm{a}}$} \\
\hline \multicolumn{1}{c}{ Model } & \multicolumn{3}{c}{ Unstandardized Coefficients $^{-1}$} & \multicolumn{1}{c}{ Sig. } \\
1 (Constant) & $\mathrm{B}$ & 8.951 & 1.459 & .156 \\
DER & & -.384 & -.072 & .943 \\
perputaran persediaan & & .831 & 6.771 & .000 \\
perputaran kas & & .009 & .227 & .822 \\
\hline
\end{tabular}

Sumber: data diolah peneliti, 2019

Berdasarkan tabel di atas dapat diketahui perhitungan uji t masing - masing variabel sebagai berikut:

a. H1 : struktur modal (DER) memiliki nilai $\mathrm{t}-0.072$ dengan nilai probabilitas signifikansi sebesar 0.943. Signifikansi t $>0.05$, maka H1 ditolak. Berarti variabel struktur modal tidak berpengaruh signifikan terhadap profitabilitas.

b. H2 : perputaran persediaan memiliki nilai t 6,771 dengan nilai probabilitas signifikansi sebesar 0.000. Signifikansi $t<0.05$, maka H2 diterima. Berarti variabel perputaran persediaan berpengaruh signifikan terhadap profitabilitas.

c. H3 : perputaran kas memiliki nilai t 0.227 dengan nilai probabilitas signifikansi sebesar 0.822. Signifikansi $\mathrm{t}>0.05$, maka $\mathrm{H} 3$ ditolak. Berarti variabel perputaran kas tidak berpengaruh signifikan terhadap profitabilitas.

b. Uji F

Tabel 4. Hasil Uji F

ANOVA

\begin{tabular}{|l|r|r|r|r|r|}
\hline Model & Sum of Squares & Df & Mean Square & F & Sig. \\
\hline $1 \quad$ Regression & 1855.443 & 1 & 1855.443 & 45.845 & $.000^{\mathrm{a}}$ \\
Residual & 1133.212 & 28 & 40.472 & & \\
Total & $2988.655^{\mathrm{b}}$ & 29 & & & \\
\hline
\end{tabular}

Sumber: data diolah peneliti, 2019

Tabel di atas, dapat dilihat nilai $\mathrm{F}$ hitung $=45.845$ lebih besar dari $\mathrm{F}$ tabel $=2.74$ atau nilai signifikansi lebih kecil dari $0.05(0.000<0.05)$, maka sesuai dengan dasar pengambilan keputusan uji $\mathrm{F}$ dapat disimpulkan bahwa hipotesis diterima, artinya secara simultan ada pengaruh struktur modal, perputaran persediaan, perputaran kas terhadap profitabilitas. 


\section{Pembahasan Hasil Penelitian}

\section{Pengaruh Struktur Modal Terhadap Profitabilitas}

Berdasarkan pengujian hipotesis yang dilakukan pada penelitian ini, maka dapat diketahui bahwa struktur modal tidak berpengaruh signifikan terhadap profitabilitas pada perusahaan sub sektor otomotif dan komponen yang terdaftar di Bursa Efek Indonesia tahun 2013-2017. Hasil penelitian menunjukkan nilai signifikansi 0,943 lebih besar dari 0,05 $(0,943>0,05)$, maka DER tidak berpengaruh terhadap ROE. Hal ini bertentangan dengan penelitian Arista dan Topowijono (2017) yang menyatakan bahwa struktur modal berpengaruh terhadap profitabilitas. Struktur modal mempunyai nilai negatif dan signifikan terhadap profitabilitas perusahaan. Struktur modal yang rendah akan meningkatkan tingkat profitabilitas, sebaliknya jika struktur modal tinggi akan menurunkan tingkat profitabilitasnya. Penggunaan hutang yang tinggi akan meningkatkan beban bunga pada perusahaan, sehingga tingginya beban perusahaan untuk melunasi kewajibannya dapat menimbulkan adanya risiko kebangkrutan pada perusahaan.

\section{Pengaruh Perputaran Persediaan Terhadap Profitabilitas}

Persediaan merupakan komponen modal kerja yang sangat penting bagi perusahaan untuk menunjang kegiatan operasionalnya. Efisiensi persediaan dapat diketahui dari tingkat perputarannya, semakin tinggi tingkat perputaran persediaan maka semakin besar pula keuntungan yang diperoleh oleh perusahaan. Perputaran persediaan berpengaruh positif dan signifikan terhadap profitabilitas pada perusahaan otomotif dan komponen di Bursa Efek Indonesia tahun 2013-2017 disebabkan oleh perusahaan cukup efisien dalam mengelola persediaannya, efisiensi di sini dapat dikatakan seperti perusahaan bisa mengurangi kredit cost, perusahaan bisa mengatasi agar bunga tidak mengendap, dan bisa mengurangi kerusakan persediaan sehingga dapat meminimalisir risiko terhadap kerugian yang disamping itu akan menghemat biaya penyimpanan dan pemeliharaan terhadap persediaan tersebut. Rasio perputaran yang tinggi menunjukkan perusahaan yang berkaitan tidak mengeluarkan biaya yang terlalu banyak untuk membeli barang dagangannya dan dapat menjauhi pemborosan-pemborosan pada sumber daya perusahannya apabila persediaan tersebut tidak terjual sesuai harapan. Perputaran persediaan yang berpengaruh positif mengindikasikan bahwa peningkatan perputaran persediaan akan meningkatkan profitabilitas perusahaan. Hasil penelitian ini konsisten dengan teori yang dikemukakan oleh Brigham (2006) yaitu jika perputaran persediaan lebih cepat maka laba berlipat ganda dan jika keadaan lain dianggap tetap. Kemampuan persediaan untuk ditransformasikan menjadi kas melalui penjualan dapat dijadikan indeks tentang seberapa besar profit margin yang dapat direalisasikan. Tingkat perputaran persediaan yang tinggi mengakibatkan kenaikan pendapatan dan meningkatkan laba dimasa yang akan datang.

\section{Pengaruh Perputaran Kas Terhadap Profitabilitas}

Kas sangat dibutuhkan perusahaan untuk menunjang kegiatan operasional perusahaan. Perputaran kas merupakan perputaran sejumlah modal kerja yang tertanam pada kas dalam satu periode. Perputaran kas dapat diketahui dengan cara membandingkan antara penjualan dengan jumlah rata-rata kas pada perusahaan. Hasil penelitian ini menunjukkan bahwa perputaran kas mempunyai nilai signifikansi sebesar 0,822 berada di atas $0,05(0,822>0,05)$, mengindikasikan bahwa perputaran kas tidak berpengaruh signifikan terhadap profitabilitas yang diukur dengan ROE pada perusahaan otomotif dan komponennya di Bursa Efek Indonesia. Hal ini berarti meningkat atau menurunnya nilai perputaran kas tidak akan memengaruhi profitabilitas perusahaan. Sementara hipotesis yang dikembangkan oleh Riyanto (2013) menyatakan bahwa perputaran kas digunakan untuk mengukur efisiensi penggunaan kas pada perusahaan yang dilihat 
dari tingkat perputarannya, kas yang berputar dengan cepat dalam satu periode mengakibatkan tingkat penjualan meningkat, hal ini berarti perusahaan akan mendapatkan keuntungan yang lebih besar dan profitabilitas perusahaan pun akan semakin baik.

\section{Pengaruh Struktur Modal, Perputaran Persediaan Dan Perputaran Kas Terhadap Profitabilitas.}

Berdasarkan hasil uji hipotesis data secara simultan variabel struktur modal, perputaran persediaan dan perputaran kas berpengaruh signifikan terhadap profitabilitas pada perusahaan sub sektor otomotif dan komponen yang terdaftar di Bursa Efek Indonesia tahun 2013-2017. Hal ini dapat dilihat dari signifikansi yang dihasilkan lebih kecil dari 0.05 , sehingga hipotesis diterima. Hasil uji $\mathrm{F}$ pada tabel diperoleh $\mathrm{F}$ hitung $=45.845$ yang lebih besar dari $\mathrm{F}$ tabel $=2.74$ dengan nilai probabilitas $=0.000$ pada taraf signifikansi 0.05 , maka sig. Sebesar $0.000<0.05$, sehingga dapat disimpulkan bahwa struktur modal, perputaran persediaan dan perputaran kas secara simultan berpengaruh signifikan terhadap profitabilitas pada perusahaan sub sektor otomotif dan komponen yang terdaftar di Bursa Efek Indonesia tahun 2013-2017. Hal ini berarti apabila struktur modal, perputaran persediaan dan perputaran kas bergerak bersama-sama akan berdampak positif pada profitabilitas. Sehingga pentingnya mengelola struktur modal, perputaran persediaan dan perputaran kas secara efektif, guna untuk memengaruhi profitabilitas. Struktur modal dan modal kerja merupakan faktor yang sangat penting dalam perusahaan, hal ini dikarenakan perusahaan membutuhkan modal dalam menjalankan aktifitasnya. Modal adalah hak atau bagian yang dimiliki suatu perusahaan yang digunakan untuk membiayai kegiatan operasional perusahaan. Perputaran persediaan dan perputaran kas selalu dalam keadaan berputar atau beroperasi dalam perusahaan selama perusahaan tersebut dalam keadaan sedang melakukan aktivitas usahanya.

\section{KESIMPULAN DAN SARAN}

Berdasarkan pembahasan hasil penelitian yang dilakukan pada bab sebelumnya, maka dapat disimpulkan hal-hal sebagai berikut:

1. Secara parsial struktur modal tidak berpengaruh signifikan terhadap profitabilitas pada perusahaan otomotif dan komponen lainnya yang terdaftar di Bursa Efek Indonesia tahun 20132017.

2. Secara parsial perputaran persediaan berpengaruh signifikan terhadap profitabilitas pada perusahaan otomotif dan komponen lainnya yang terdaftar di Bursa Efek Indonesia tahun 20132017.

3. Secara parsial perputaran kas tidak berpengaruh signifikan terhadap profitabilitas pada perusahaan otomotif dan komponen lainnya yang terdaftar di Bursa Efek Indonesia tahun 20132017.

4. Secara simultan struktur modal, perputaran persediaan dan perputaran kas berpengaruh signifikan terhadap profitabilitas pada perusahaan otomotif dan komponen lainnya yang terdaftar di Bursa Efek Indonesia tahun 2013-2017.

Saran bagi pihak manajemen, perusahaan yang menggunakan pendanaan dari luar sebaiknya memerhatikan kondisi ekonomi dan kondisi keuangan perusahaan saat menggunakan hutang jangka panjang karena penggunaannya dapat menimbulkan beban bunga. Bagi para investor, dalam menentukkan strategi keuangannya dapat mempertimbangkan faktor keputusan pendanaan yang berkaitan dengan porsi hutangnya. Bagi peneliti selanjutnya diharapkan melakukan penelitian lanjutan dengan menggunakan rasio keuangan yang berbeda, yang belum dimasukkan dalam penelitian ini atau dengan menambah variabel baru yang dapat memberikan kontribusi terhadap profitabilitas. 


\section{REFERENSI}

Ambarwati, Sri Dwi Ari, 2010. Manajemen Keuangan Lanjut, Graha Ilmu, Yogyakarta.

Arista dan Topowijono, 2017. pengaruh struktur modal terhadap profitabilitas (studi pada peruahaan sub sektor otomatif dan komponen yang tedaftar di Bursa Efek Indoneia periode 2013-2015, Jurnal Administrasi Bisnis, Vol 46 No 1.

Brigham dan houston, 2006. Dasar-Dasar Manajemen Keuangan Buku 1, Salemba Empat, Jakarta. Harjito dan Martono, 2014. Manajemen Keuangan, Edisi ke 2, EKONISIA, Yogyakarta.

Harmono, 2017. Manajemen Keuangan, Berbasis Balanced Scorecard Pendekatan Teori, Kasus, dan Riset Bisnis, PT Bumi Aksara, Jakarta.

Kasmir, 2010. Pengantar Manajemen Keuangan,Kencana Prenada Media Grup, Jakarta.

Mulyawan, Setia, 2015. Manajemen Keuangan, CV Pustaka Setia, Bandung.

Riyanto, Bambang 2013, Dasar-dasar Pembelanjaan Perusahaan, Edisi Keempat. Cetakan Kesembilan . BPFE. Yogyakarta

Sutojo, Siswanto, dan Fritz, Kleinsteuber. 2004.Manajemen Keuangan Bagi Eksekutif NonKeuangan, PT Damar Mulia Pustaka, Jakarta.

Sutrisno, 2013. Manajemen Keuangan (Teori, Konsep, dan Aplikasi). Edisi Pertama, EKONISIA, Yogyakarta.

Sugiyono, 2015. Metode Penelitian Manajemen, Alfabeta, Bandung.

http://www.web.Industri.Manufaktur.Otomotif.Indonesia.Penjualan.Mobil.Indonesia.Investments.h tm 